\title{
Immunobioinformatics of Rabies Virus in Various \\ Countries of Asia: Glycoprotein Gene \\ by Jola Rahmahani
}

Submission date: 16-Aug-2021 11:44AM (UTC+0800)

Submission ID: 1631866137

File name: obioinformatics_of_Rabies_Virus_in_Various_Countries_of_Asia.pdf (131.13K)

Word count: 2397

Character count: 13268 


\title{
$\underline{\text { RESEARCH ARTICLE }}$
}

\section{2 Immunobioinformatics of Rabies Virus in Various Countries of Asia: Glycoprotein Gene}

\author{
Amaq Fadholly $^{1}$, Arif N. M. Ansori ${ }^{1}$, Viol D. Kharisma ${ }^{2}$, Jola Rahmahani ${ }^{3}$, \\ Marti 8 R. Tacharina ${ }^{3 *}$ \\ ${ }^{1}$ Doctoral Program in Veterinary Science, Faculty of Veterinary Medicine, Universitas Airlangga, \\ Surabaya, Indonesia. \\ ${ }^{2}$ Faculty 11 Mathematics and Natural Sciences, Universitas Brawijaya, Malang, Indonesia. \\ ${ }^{3}$ Department of Veterinary Microbiology, Faculty of Veterinary Medicine, Universitas Airlangga, \\ Surabaya, Indonesia. \\ *Corresponding Author E-mail: martia.rt@fkh.unair.ac.id
}

\begin{abstract}
ABSTRAC' $T 16$
The purpose of this study was to analyze the genomic information of the glycoprotein gene of rabies virus $20 \mathrm{ABV}$ ) in several countries of Asia. The genomics information of vaccine virus strain and some local isolates were retrieved from GeneBank ${ }^{\circledR}$ (National Center for Biotechnology Information, USA). Ten genomics informations are consist of ERA vaccine virus, two viruses from Indonesia, a virus from Myanmar, India, Nepal, South Korea, Japan, Sri Lanka, and Iran. This bioinformatics process the ten genomics data in order to find pattern in 1,575 bp of glycoprotein gene of RABV. In conclusion, this study have revealed the data of homology, B-cell epitope prediction, genetic distance, and molecular phylogenic analysis of RABV in various countries of Asia. We indicated that the glycoprotein, the immunogenic surface protein of RABV, has important part for vaccine design.
\end{abstract}

KEYWORDS: Bioinformatics, Lyssavirus, glycoprotein, rabies, vaccine.

\section{TRODUCTION:}

Rabies is an ancient lethal zoonotic disease that is caused by Lyssavirus called RABV which is a member of Rhabdoviridae. Rabies is invariably fatal in human and mammals for over 4000 years in all across the continents ${ }^{1}$. Dogs are the most important reservoir for rabies and around $99 \%$ in human cases of dog bites ${ }^{2}$. Rabies were also detected due to exposure to rabid cats and wildlife. The disease is often reported as a disease of poverty, ignorance in some circumstances and misinformation ${ }^{3}$.
The rabies situation in Asia is characterized by high rate of human mortalities. Only few countries in Asia (Hong Kong, Japan, Malaysia, Singapore, Taiwan) have eradicated rabies through vaccination and stray programs in $\operatorname{dog} s^{4}$. World Health Organization (WHO) of South, Southeast, East Asia region stated that there are eleven countries (Bangladesh, Bhutan, India, Indonesia, Korea, Maldives, Myanmar, Nepal, Srilanka, Thailand, TimorLeste) and eight of them are endemic for rabies. Rabies cases in Indonesia are progressively increase the status from low to medium rabies endemic country. It is emerging problem because previously many isla $9 \mathrm{~s}$ of Indonesia considered free of 9 bies $^{5}$. Therefore, a joint project of WHO-OIE-FAO plans to eliminate rabies cases worldwide by the year $2030^{6}$.

7

RABV encodes five proteins: the nucleoprotein $(\mathrm{N})$, phosphoprotein (P), matrix protein (M), glycoprotein (G), and RNA polymerase (L). G protein is a surface protein in RABV that has high immunogenic potency. Hence 17 protein is the target protein in rabies vaccine ${ }^{7}$. The attenuated live vaccine strain Evelyn-Rokitnicki- 
3

Abelseth (ERA) and Flury low egg passage vaccine are the most used antigenic properties that estimated to be sufficient to block rabies transmission in the body ${ }^{8}$. The properties can also be used as viral characterization to collect the diversity of Lyssavirus genus, enhanced surveillance and sequencing technologies ${ }^{9}$.

However, this study applied bioinformatics analysis to reveal the data of homology, pathotype, B-cell epitiope prediction, and genetic distance with phylogenetic tree of RABV in Southeast Asia through a database of isolates in GeneBank ${ }^{\circledR}$. The result of this study can be used as a data reference for vaccine virus design study to eliminate the rabies.

\section{MATERIAL AND METHODS:}

Rabies Virus Isolates:

All isolates were adopted from Gen Bank ${ }^{\circledR}$ (National Center of Biotechnology Information, USA) (Table 1.)

Table 1. Rabies virus isolates
\begin{tabular}{|l|l|l|l|}
\hline 1 & AF 406693.2 & ERA & 2005 \\
\hline 2 & EU086151.1 & Indonesia & 2011 \\
\hline 3 & AB 115921.1 & Indonesia & 2003 \\
\hline 4 & EU086129.1 & Myanmar & 2008 \\
\hline 5 & KR 105372.1 & India & 2015 \\
\hline 6 & JX 944593.1 & Nepal & 2013 \\
\hline 7 & DQ076105.1 & Korea & 2005 \\
\hline 8 & AB 817146.1 & Japan & 2013 \\
\hline 9 & EU086156.1 & Sri Lanka & 2008 \\
\hline 10 & JX 987734.1 & Iran & 2013 \\
\hline
\end{tabular}

Nucleotide Sequence Preparation:

RABV nucleotide sequences (glycoprotein gene: 1575 bp) from all isolates were adopted from GenBank ${ }^{\circledR B}$ (National Center of Biotechnology Information, USA). Multiple sequence alignment of nucleotide sequences were analyzed with BioEdit vers. 7.
Sequence Homology:

19

The ten isolates of RABV we used in this study were alligned and the homology analysis were identified using Needleman-Wunsch Global Align Nucleotide Sequences of NCBI.

Predicition of B Cell Epitop and Protective Antigens: The antigenic determinant or epitope of whole $G$ protein gene were used IEDB Online Web server. The part of these antigen that binds to a specific antigen receptor on the surface of mamalian B cell were predicted using Vaxi Jen v2.0.

Genetic Distance and Molecular Phylogenetic Analysis:

Genetic distanced were analyzed using MEGA X with the Kimura two-parameter method. Molecular phylogenetic were obtained by maximum likelihood as phylogenetic tree using a bootstrap test on 1000 replication with Tamura-Nei substitution model.

\section{RESULTS AND DISCUSSION:}

The results of homology analysis were count to compared with ERA as vaccine strain. are presented in Table 2. The higher scores of homology showed closer genetic relationship. The isolates of RABV that closest with ERA was isolate of Iran/Middle-East (92\%), followed by India/South (89\%), Nepal/South (87\%), Korea/East (86\%), Indonesia/Southeast and Japan/East (84\%), Sri Lanka/South (83\%). Two isolates from Indonesia actually got mutation or different variance, showed in homology scores that the isolates were not identically $100 \%$. Some of the isolates showed no significant similarity found like Indonesia/SoutheastNepal/South, Indonesia/ Southeast-Korea/ East, Myanmar/ Southeast-Iran/ Midlle-East, and Nepal/ South-Japan/ East.

Table 2. The results of homology analysis of rabies virus using Needleman-Wunsch Global Align Nucleotide Sequences (NCBI, USA).

\begin{tabular}{|c|c|c|c|c|c|c|c|c|c|c|}
\hline \multirow[t]{2}{*}{ Isolates } & \multicolumn{10}{|c|}{ Homology scores (\%) } \\
\hline & 1 & 2 & 3 & 4 & 5 & 6 & 7 & 8 & 9 & 10 \\
\hline $\begin{array}{l}\text { ERA } \\
\text { (Vaccine) }\end{array}$ & 100 & & & & & & & & & \\
\hline Indonesia & 84 & 100 & & & & & & & & \\
\hline Indonesia & 84 & 97 & 100 & & & & & & & \\
\hline Myanmar & 83 & 88 & 88 & 100 & & & & & & \\
\hline India & 89 & 85 & 85 & 85 & 100 & & & & & \\
\hline Nepal & 87 & - & - & 84 & 87 & 100 & & & & \\
\hline Korea & 86 & - & 85 & 85 & 87 & 91 & 100 & & & \\
\hline Japan & 84 & 85 & 85 & 85 & 85 & - & 85 & 100 & & \\
\hline Sri Lanka & 83 & 84 & 84 & 84 & 84 & 84 & 84 & 92 & 100 & \\
\hline Iran & 92 & 85 & 85 & - & 85 & 88 & 87 & 85 & 84 & 100 \\
\hline
\end{tabular}

In addition, all protein's sequences of glycoprotein were antigenic, showed in Table 3. Isolate of Sri Lanka/South selected from NCBI website to get conserved region of has the highest predictive score, 23.96 and RABV. We used ten conserved epitopes that have 'GNQAGSKQHGLEGTGRKVSVTSQNGKVI' as affinity of binding B cell while there are eight epitopes potential antigenic peptide, followed by Korea/East, presence antigenic and only two epitopes as non- 22.91, Indonesia/ Southeast, 21.12 and 
3

'VNRPKSTQHNLGGTGRKVSVTSOSGKVI', 'NRAESIQHSSGETGRKVSVTSQNGR' as potential antigenic peptide. Both isolates of Myanmar/Southeast and India/South have the same prediction score as nonantigenic while the lowest prediction score was another Indonesia isolate, 11.19 but still as potential antigenic peptide.

\section{1}

Table 3. The results of B-cell epitope prediction analysis and antigenicity of rabies virus isolates using Immune Epitope Database and Analysis Resource (IEDB) and Vaxi,Jen v2.0.

\begin{tabular}{|l|l|l|l|}
\hline $\begin{array}{l}\text { ERA } \\
\text { (Vaccine) }\end{array}$ & $\begin{array}{l}\text { KMAGDPRYEESLHNPYP } \\
\text { DY }\end{array}$ & 18.01 & Antigen \\
\hline Indonesia & $\begin{array}{l}\text { NRAESIQHSSGETGRKVS } \\
\text { VTSQNGR }\end{array}$ & 21.12 & Antigen \\
\hline Indonesia & $\begin{array}{l}\text { HSLGETGRK VSVTSQNG } \\
\text { R }\end{array}$ & 11.19 & Antigen \\
\hline India & $\begin{array}{l}\text { KMAGDPRYEESLHNPYP } \\
\text { D }\end{array}$ & 17.45 & Non \\
D
\end{tabular}

Identification of B-cell epitopes is high importance for many medical applications including disease control and 5. ccine development. B-cells can neutralize pathogenic molecules by targeting them with extreme specificity using receptors expressed on their surface or antibodies via interaction between binding site as paratope and a specific region of the antigen as epitope ${ }^{10}$. This identifying is a great interest for understanding disease etiology, immune monitoring, developing diagnosis assay and designing epitope-based vaccines. A good epitope commonly has more than nine peptides ${ }^{11}$. In this case, all isolates have more than nine peptides which is good as an epitope then immunogenicity determined how the peptides become potential antigen or nonantigen.

The results of molecular phylogenetic as genetic distance analysis ( $p$-analysis) will be correlated to vaccination results. If the genetic distance of field viruses is quite far from the vaccine virus it will affect the effectiveness of vaccination because the antibodies introduction determined the repeat vaccination program. Isolates from Nepal/South, Korea/East and Iran/Middle-East have close genetic relationship as well as other isolates from Japan/East and Sri Lanka/South. Uncommonly Korea and Japan as country in East Asia got separated group of genetic relationship while Myanmar and Indonesia as country in Southeast Asia got the same group of genetic relationship. Isolates from India/South was quite far from the other isolates and ERA as vaccine virus still collerated to other isolates except India/South.

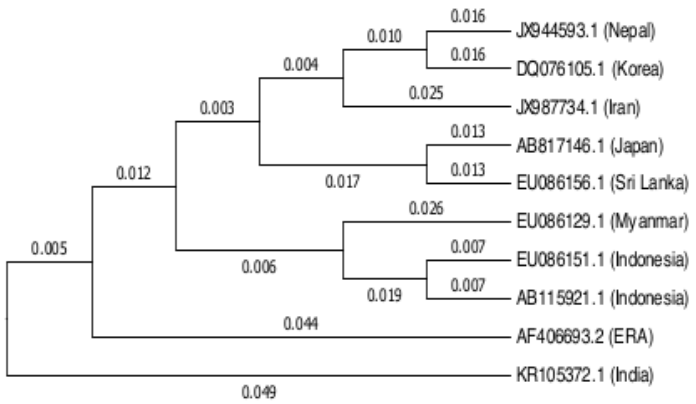

Figure 1. The results of molecular phylogenetics analysis of rabies virus.

Phylogenetics is known as a field related to biological sciences that provide data of biological evolution ${ }^{4}$. However, the possibility of mutation or combination of a field virus and vaccine virus should be analyzed used genome sequences of the isolate ${ }^{12}$. To the next study, isolates from Korea, Japan, and India must be carried more than one sequence to compare the result of this study and gain the glycoprotein gene data. On the other hand, previous study revealed the genetic relationship between RABV in Asia based on $\mathrm{N}$ gene ${ }^{13}$.

The importance of selecting RABV in this study was based on many contributed high mortality rates to produce rabies vaccine. This data has shown that the establishment of glycoprotein gene of RABV is still needed as antigenic peptide and vaccination against viral diseases is very important for protection, due to the lack of appropriate consuming antiviral drugs and high $\operatorname{cost}^{14}$. The challenges associated with rabies vaccines are exciting because they have potential to reveal fundamental features of immune memory against antigenically variable pathogens and prime for vaccine development.

addition, vaccination is a highly effective approach to disease control in veterinary health care. Vaccine is a 1 olecular or supramolecular agent that is an enhanced adaptive 1 immune response to re-infection by pathogenic 1 ents through the potentiation of immune memory. accination ultimately mitigates the effect of subsequent 1 fection and disease. Thus, the immune system recognizes vaccine agents as foreign, then destroys and remembers them. Furthermore, genomics has 1 volutionized vaccine development study. The ability to 1 quence the whole genome of a virulent microorganism has led some to screen in silico for the most probable protective an1gens before undertaking confirmatory experiments. Apart from obvious advantages, such as 
leed and low cost, the success of this approach is 1 pendent on the accuracy of antigen prediction, and many bioinformatics tools are available to facilitate this process $^{15}$.

\section{CONCLUSION:}

In conclusion, vaccine development is an important issue. This study has revealed the data of homology, B cell epitope prediction, genetic distance, and the molecular phylogenic analysis of RABV in various countries of Asia. Furthermore, the results of glycoprotein gene of RABV are still exist and indicated that this protein is functionally important as a part for another rabies vaccine virus design, antibody crossreactivity, and in silico antibody library screening.

\section{ACKNOWLEDGEMENT:}

This study was supported by PMDSU Grant Funds with 10erence number 1341/UN3.14/LT/2018 from The Ministry of Research, Technology, and Higher Education (KEMENRISTEKDIKTI) of The Republic of Indonesia.

\section{CONFLICT OF INTEREST:}

The authors declare no conflict of interest.

\section{REFERENCES:}

1. Fisher CR, Streicker DG, Schnell MJ. The spread and evolution of rabies virus: conquering new frontiers. Nature Review Microbiology. 2018; 16: 241-255.

2. Fooks AR, Cliquet F, Finke S, Freuling C, Hemachudha T, Mani RS, Müller T, Nadin-Davis S, Picard-Meyer E, Wilde H, Banyard AC. Rabies. Nature Reviews Disease Promers. 2017; 3: 17091.

3. Warrell MJ. The dillema of managing human rabies encephalitis. Trop Med Int Health. 2016; 21: 456-457.

4. Tenzin, Ward MP. Review of rabies epidemiology and control in south, south east and east asia: past, present and prospects for elimination. Zoonoses and Public Health. 2012; 59(7): 451-467.

5. Gongal G, Wright AE. Human rabies in the WHO Southeast Asia Region: Foward Steps for Elimination. Adv Prev Med. 2011; Article ID 383870

6. El-Sayed A. Advances in rabies prophylaxis and treatment with emphasis on immunoresponses mechanisms. Int J Vet Sci Med. 2018; 6(1): 8-15.

7. Hicks D, Fooks A, Johnson N. Developments in rabbies vaccines. Clin Exp Immunol. 2012; 169: 199-204.

8. Yang D, Kim H, Lee W, Song J. The present and future of rabies vaccine in animals. Clin Exp Vaccine Res. 2013; 2(1): 19-25.

9. Banyard AC, Fooks AR. The impact of novel lyssavirus discovery. Microbiol Australia. 2017; 38: 18-21.

10. Jespersen MC, Mahajan S, Peters B, Nielsen M, Marctili P. Antibody spesific B-cell epitope predictions: leveraging information from antibody-antigen protein complexes. Front Immunol. 2019; 10: 298

11. Sanchez-Trincando JL, Gomez-Perosanz M, Reche PA. Fundamentals and methods for T-and B-cell epitope prediction. J Immunol Res. 2017; 2680160.

12. Marston DA, Horton DL, Nunez J, Ellis RJ, Orton RJ, Johnson N, Banyard AC, McElhinney LM, Freuling CM, Firat M, Ünal N, Müller T, Lamballerie X, Fooks AR, Genetic of analysis of a rabies virus host shift event reveals within-host viral dynamics in a new host. Virus Evol. 2017;3(2): vex038.
13. 6 hmahani J, Suwamo S, Yuniarti WM, Rantam FA. Antigenic site of nucleoprotein gene from Indonesian rabies virus isolates. 4 terinary World. 2019;12(5): 724-728.

14. Yousaf MZ, Qasim M, Zia S, Khan MR, Ashfaq UA, Khan S Rabies molecular virology, diagnosis, prevention and treatment. 5 Virology Journal. 2012; 9(50).

15. 12 tchinova IA, Flower DR. Vaxijen: a server for prediction of protective antigens, tumour antigens and subunit vaccines. BMC Bioinformatics. 2007; 8: 4 .

\section{6.}


Immunobioinformatics of Rabies Virus in Various Countries of Asia: Glycoprotein Gene

ORIGINALITY REPORT

$19 \%$

SIMILARITY INDEX

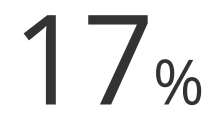

INTERNET SOURCES
$17 \%$

PUBLICATIONS
$0 \%$

STUDENT PAPERS

PRIMARY SOURCES

1 bmcbioinformatics.biomedcentral.com

2 rjptonline.org

3 idoc.pub

Internet Source

4 www.neurologiepropraxi.cz

Internet Source

5 doi.org

Internet Source

6 amedeo.com

Internet Source

Emilie M. Bonnaud, Cécile Troupin, Laurent Dacheux, Edward C. Holmes et al.

"Comparison of intra- and inter-host genetic diversity in rabies virus during experimental cross-species transmission", PLOS Pathogens, 2019 
9

A El-Sayed. "Advances in rabies prophylaxis and treatment with emphasis on immunoresponse mechanisms", International Journal of Veterinary Science and Medicine, 2018

Publication

10 wWw.mdpi.com Internet Source

11 wvj.science-line.com Internet Source

12 benthamopen.com

13 www.uobabylon.edu.iq

Tenzin, â€f, and M. P. Ward. "Review of

Rabies Epidemiology and Control in South, South East and East Asia: Past, Present and Prospects for Elimination : Rabies in Asia", Zoonoses and Public Health, 2012.

\section{Publication}


17 www.ncbi.nlm.nih.gov

18

Ashley C. Banyard, Anthony R. Fooks.

"Chapter 1 Rabies Life Cycle, Transmission

and Pathogenesis", Springer Science and

Business Media LLC, 2020

Publication

19 Buddhi Pantha, Sunil Giri, Hem Raj Joshi,

Naveen K. Vaidya. "Modeling transmission

dynamics of rabies in Nepal", Infectious

Disease Modelling, 2021

Publication

20 idpjournal.biomedcentral.com 